\title{
Germline and somatic mosaicism in a female carrier of Hunter disease
}

\author{
Roseline Froissart, Irène Maire, Véronique Bonnet, Thierry Levade, Dominique Bozon
}

\begin{abstract}
Carrier detection in a mucopolysaccharidosis type II family (Hunter disease) allowed the identification of germline and somatic mosaicism in the patient's mother: the R443X mutation was found in a varying proportion in tested tissue $(7 \%$ in leucocytes, lymphocytes, and lymphoblastoid cells, and $22 \%$ in fibroblasts). The proband's sister carries the at risk allele (determined by haplotype analysis), but not the mutation. In sporadic cases of $X$ linked diseases, germline mosaicism of the proband's mother is difficult to exclude and should be considered in genetic counselling.

( $\mathcal{F}$ Med Genet 1997;34:137-140)
\end{abstract}

Keywords: mucopolysaccharidosis type II; mosaicism; mutation.

Hunter disease or mucopolysaccharidosis type II (MPS II) is an X linked lysosomal storage disease resulting from the deficiency of iduronate-2-sulphatase (IDS, EC 3.1.6.13). ${ }^{1}$ The IDS gene has been mapped to Xq28. ${ }^{2} \mathrm{~A}$ full length cDNA clone containing an open reading frame of $1650 \mathrm{bp}$ has been isolated and sequenced. ${ }^{3}$ The IDS gene spans $24 \mathrm{~kb}$ and contains nine exons ${ }^{45}$ and has been completely sequenced $^{6}$ (GenBank accession number L43581). A pseudogene located $20 \mathrm{~kb}$ distal to the active gene has been characterised ${ }^{6}$ and is involved in recombinations with the IDS gene. ${ }^{78}$ Various IDS locus alterations have been described, ${ }^{9-12}$ such as large deletions and rearrangements, but about $80 \%$ of the mutations are point mutations, minor deletions, or insertions. Most of them are private except for some that more frequently occur on $\mathrm{CpG}$ dinucleotides.

Female carriers of MPS II are asymptomatic though they often show decreased levels of IDS activity in serum or leucocytes or both. Cloned fibroblasts ${ }^{13}$ or hair roots ${ }^{14}$ have also been studied for carrier detection. However, attempts to identify carriers by enzyme assays have often led to ambiguous results because of nonrandom $\mathrm{X}$ inactivation. Indirect genotype analysis using intragenic and closely linked flanking polymorphisms, combined with enzymatic and pedigree analyses, allows carrier detection in some but not all families. ${ }^{15}$ Identification of the mutation in a patient with MPS II allows fast and reliable carrier detection in related at risk females.

The carrier status of females in a family with an isolated case of Hunter disease was studied by haplotype, enzyme analysis, and mutation identification. This study led to the identification of germline and somatic mosaicism in the proband's mother.

\section{Material and methods}

CASE REPORT

The patient was the first child of healthy parents. The diagnosis was suspected at 3 years but was assessed at 6 years; increased excretion of glycosaminoglycans (heparan sulphate and dermatan sulphate) in urine was found as well as IDS deficiency in serum. He is now 17 years old and presents with coarse facial features, enlarged tongue, kyphosis, joint stiffness that has required surgery, short stature, hepatosplenomegaly, cardiopathy (mitral and aortic insufficiency, mitral stenosis), deafness, and mental retardation. The pedigree of the family is shown in fig 1 .

\section{IDS ACTIVITY}

IDS activity was determined using the reagent kit provided by The Hospital for Sick Children, Toronto, Canada as previously described. ${ }^{16}{ }^{17}$

\section{POLYMORPHIC MARKERS}

Genomic DNA was extracted from leucocytes, lymphocytes, fibroblasts, or lymphoblastoid cells according to Jeanpierre. ${ }^{18}$ Genomic DNA from leucocytes was digested by StuI, TaqI, and BanI. Southern blotting was carried out using standard procedures. DNA probes, radiolabelled with $\alpha^{32} \mathrm{P}-\mathrm{dCTP}$ by random priming, included: IDS cDNA $(1.7 \mathrm{~kb} \quad$ NotI/XhoI fragment from the cDNA clone pB2Sc17 containing the complete coding region of IDS), probe II-10 at locus DXS466, ${ }^{19}$ probe U6.2$20 \mathrm{E}$ at locus DXS304, ${ }^{20}$ and probe VK21A at locus DXS296. ${ }^{21}$ Haplotypes were determined with the StuI intragenic polymorphism (in intron 8) and three extragenic polymorphisms, BanI (U6.2-20E) and TaqI (II-10 and VK21A).

A microsatellite at locus DXS1113, located $10 \mathrm{~kb}$ distal to the IDS gene, was analysed as described by Weber et al. ${ }^{22}$

AMPLIFICATION OF GENOMIC DNA

Exon 9 was amplified as a $580 \mathrm{bp}$ fragment with oligonucleotides 5'I: 5'CCATTCTGCTCTGTCGCTTC-3' (nt 54371-54352 in intron 8) and V6: 5'CAAAACGACCAGCTCTAACTC-3' (nt 53792-53812 in exon 9). PCR conditions were: $94^{\circ} \mathrm{C}$ for 30 seconds, $61^{\circ} \mathrm{C}$ for 30 seconds, and $72^{\circ} \mathrm{C}$ for 45 seconds, for 30 cycles. 


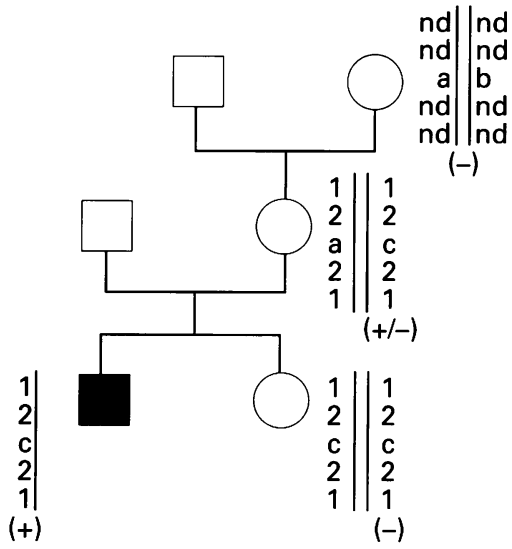

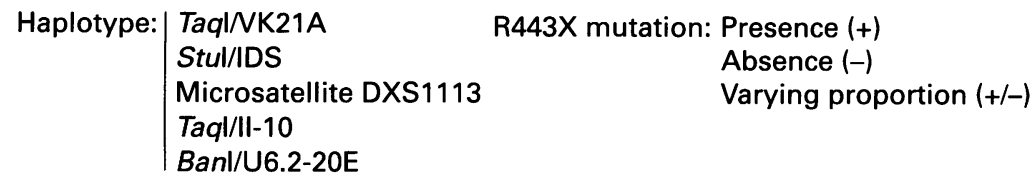

nd: not determined

Figure 1 Family pedigree showing the segregation of the haplotypes and $R 443 X$ mutation.

Amplification of genomic DNA from hair roots was performed as follows: each hair root was rinsed in distilled water and in $100 \%$ ethanol, then heated to $94^{\circ} \mathrm{C}$ for 30 minutes in PCR buffer. Amplification was performed with two sets of primers: $5^{\prime} \mathrm{I} / \mathrm{V} 6$ and microsatellite DXS1113 primers ${ }^{22}$ for 30 seconds at $94^{\circ} \mathrm{C}, 45$ seconds at $60^{\circ} \mathrm{C}$, and one minute at $72^{\circ} \mathrm{C}$, for 30 cycles.

EXON 9 SEQUENCING

After amplification, PCR products were purified on a $5 \%$ acrylamide gel and directly sequenced with the Thermosequenase cycle sequencing kit (Amersham) using $\gamma^{33}$ P-ATP.

\section{R443X MUTATION ANALYSIS \\ Allele specific oligonucleotide (ASO) \\ hybridisation}

The PCR products were analysed by ASO hybridisation. ASO used for the detection of the normal and mutant $\mathrm{R} 443 \mathrm{X}$ sequences were 5'-AGCATTTTCGATTCCG-3' and 5'AGCATTTTTGATTCCG-3' respectively. Washing conditions were $5 \times \mathrm{SSC}$ at $37^{\circ} \mathrm{C}$ for $2 \times 10$ minutes, and $2 \times \mathrm{SSC}$ at $42^{\circ} \mathrm{C}$ for $3 \times 15$ minutes.

\section{TaqI digestion}

The R443X mutation abolishes a TaqI site. After digestion of the PCR products, the mutation is detected by the presence of an abnormal

Table 1 IDS activity in various samples of the patient and his family

\begin{tabular}{llll}
\hline & $\begin{array}{l}\text { Serum } \\
\left(\text { pmol. } h^{-1} \cdot m l^{-1}\right)\end{array}$ & $\begin{array}{l}\text { Leucocytes } \\
\left(p m o l . h^{-1} \cdot m g^{-1}\right)\end{array}$ & $\begin{array}{l}\text { Lymphoblastoid cells } \\
\left(p m o l . h^{-1} \cdot m g^{-1}\right)\end{array}$ \\
\hline $\begin{array}{l}\text { Patient } \\
\text { Mother }\end{array}$ & 1355 & 77 & 0.5 \\
$\begin{array}{l}\text { Sister } \\
\text { Grandmother }\end{array}$ & 1785 & & 44 \\
$\begin{array}{l}\text { Control } \\
\text { Normal }\end{array}$ & 1301 & 152 & 62 \\
$\quad 1185-1900$ & 118 & 44 \\
range & & $75-158$ & $20-65$ \\
\hline
\end{tabular}

$580 \mathrm{bp}$ band instead of the normal 410 and 170 bp bands.

Quantitative PCR

To assess the relative proportion of mutant (R443X) and normal DNA, exon 9 was amplified as described previously for 29 cycles, and 1 $\mu \mathrm{Ci}$ of $\alpha^{32} \mathrm{P}$-dCTP was added before the last cycle. Radiolabelled PCR products were digested by $T a q \mathrm{I}$ and separated on an $8 \%$ acrylamide non-denaturing gel. The gel was dried and autoradiographed. Radioactivity of each band was quantified by scanning the film. Then the bands were cut from the dried gel and radioactivity content estimated by scintillation counting.

\section{Results}

IDS ACTIVITY

IDS activity was borderline in the mother's leucocytes and within the normal range in serum and lymphoblastoid cells (table 1). IDS activity was found to be normal in the grandmother's leucocytes and serum and in the sister's lymphoblastoid cells. Study of 25 fibroblast clones from the sister did not show any deficient clone (data not shown).

\section{HAPLOTYPE ANALYSIS}

The results of haplotype analysis are shown in fig 1: microsatellite DXS1113 was the only informative marker. Unexpectedly, the patient's sister had inherited from her mother the same $\mathrm{X}$ chromosome as her brother.

\section{MUTATION R443x}

Exon 9 was systematically sequenced (presence of several mutational hot spots ${ }^{910}{ }^{12}$ ), allowing the identification of the R443X mutation in the patient's genomic DNA. The presence of this mutation was tested in the mother's leucocytes by TaqI digestion of exon 9 PCR product: this showed an abnormal distribution of digested and undigested PCR products (not shown). The mother's genomic DNA extracted from various sources (leucocytes, lymphocytes, lymphoblastoid cells, fibroblasts, and hair roots) was analysed by ASO hybridisation to test the hypothesis of somatic mosaicism: the mutant allele was present with a low and varying intensity (fig 2). The mutation was not detected in the grandmother's leucocytes nor in the leucocytes of the sister who had inherited the at risk haplotype.

DNA from 35 separate hair roots of the mother was used as template for PCR and R443X analysis: only one of them hybridised with both normal and mutant probes. Microsatellite analysis (DXS1113) was performed on each hair root and confirmed the presence of the two alleles (mother's karyotype 46,XX).

The relative proportion of mutant and normal DNA in the mother's cells was assessed by quantitative PCR (fig 3). In control DNA, only the 410 and $170 \mathrm{bp}$ bands were detected, and in the DNA from an obligate carrier radioactivity of the abnormal 580 bp band represented about $50 \%$ of the total radioactivity, as expected. For the patient's mother, the 

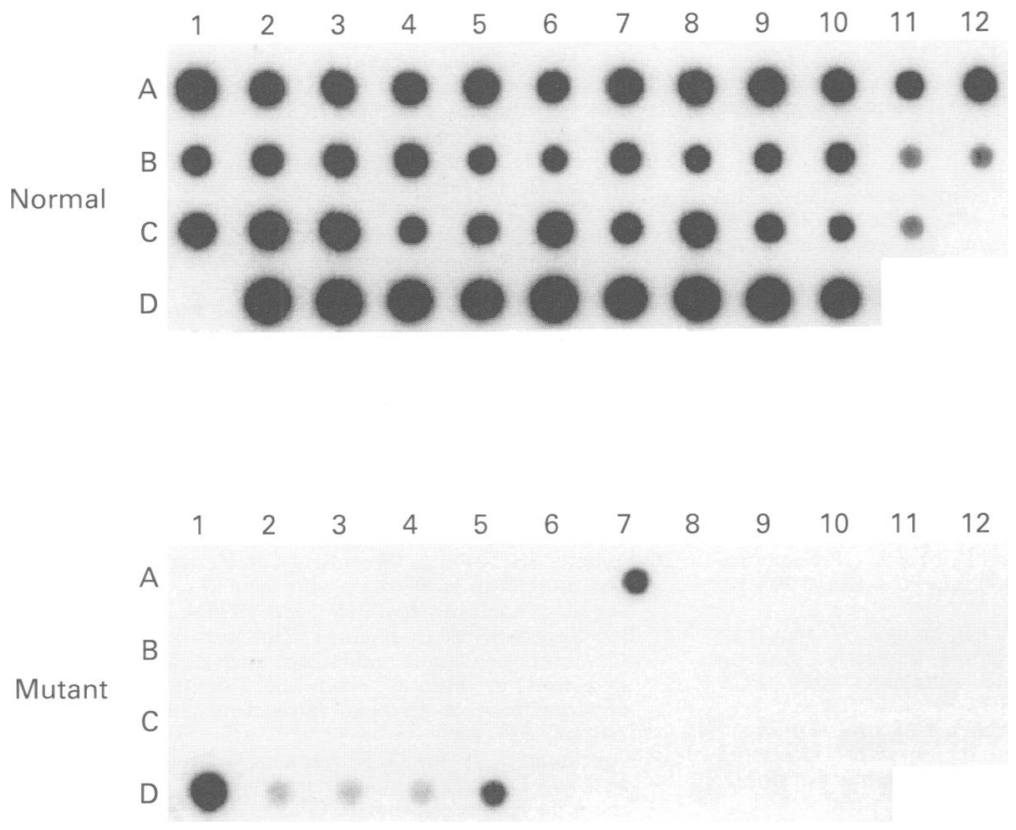

Figure 2 Detection of the R443X mutation by allele specific oligonucleotide hybridisation. After amplification of exon 9 as a 580 bp fragment, the R443X mutation was tested for after hybridisation with the normal and the mutant probes. Mother's hair roots ( $A 1$ to C11). Patient's fibroblasts (D1). Mother's leucocytes (D2), lymphocytes (D3), lymphoblastoid cells (D4), fibroblasts (D5). Grandmother's leucocytes (D6), fibroblasts (D7). Sister's lymphoblastoid cells (D8), fibroblasts (D9). Control leucocytes (D10).

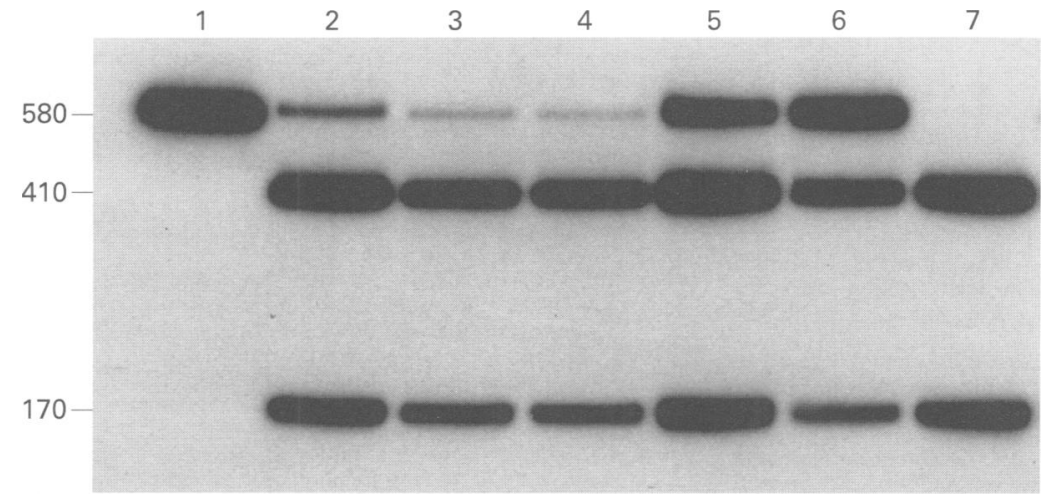

Figure 3 Quantitative PCR. Exon 9 was radiolabelled during the PCR and digested with TaqI. In normal DNA, the 580 bp fragment is cut into 410 and 170 bp fragments. The $R 443 X$ mutation abolishes a TaqI site and is detected by the presence of a $580 \mathrm{bp}$ fragment. The relative proportion of mutant and normal DNA was quantified by autoradiography and scintillation counting. Patient's fibroblasts (lane 1), mother's leucocytes (lane 2), mother's lymphocytes (lane 3), mother's lymphoblastoid cells (lane 4), mother's fibroblasts (lane 5), heterozygote's leucocytes (lane 6), control leucocytes (lane 7). DNA fragment sizes are given in base pairs.

proportion of the abnormal $580 \mathrm{bp}$ band was about $7 \%$ in leucocytes, lymphocytes, and lymphoblastoid cells, and $22 \%$ in fibroblasts.

\section{Discussion}

Carrier detection in this family was first performed by measurement of IDS activity and haplotype analysis: the results of IDS activity were inconclusive for the mother, and the carrier status of the patient's sister could not be determined.

The R443X mutation was later identified in the patient. This mutation, which occurs on a CpG dinucleotide, introduces a stop codon at position 443 and creates a truncated, nonfunctional protein. ${ }^{23}$ This mutation has been described in several patients of different ethnic origin. ${ }^{23-25}$ Haplotype and mutation analysis showed that the mother carries a mutant or wild type sequence on the same chromosome. The low proportion of mutant chromosomes varied from tissue to tissue but remained lower than in a normal carrier (the highest proportion was observed in fibroblasts). These results suggest somatic mosaicism in the mother. Her daughter, who inherited the at risk haplotype, does not carry the R443X mutation and could be excluded as a carrier. Therefore, our findings strongly support the existence of both germinal and somatic mosaicism in the mother.

Somatic mosaicism can be easily detected when the proportion of mutant cells is very different from $50 \%$. However, the finding of a classical heterozygote status in leucocytes does not rule out mosaicism and, in some instances, both haplotype and sequence analysis have been necessary to recognise mosaicism. ${ }^{26}$

To date, no case of somatic and germinal mosaicism in Hunter disease has been reported. In a previous report, Ben Simon-Schiff et $a l^{7}$ suggested the presence of germinal mosaicism in an obligate carrier, based on discordance of normal IDS activity in serum and random $\mathrm{X}$ inactivation, but no clear evidence of germline mosaicism was obtained.

Several mechanisms have been proposed for the occurrence of somatic and germline mosaicism. The most likely explanation for the existence of two populations of cells in the mother is that the mutation occurred as a result of a mitotic error at an early embryonic stage; the postzygotic mitotic mutation must have occurred early enough to be transmitted to her germline cells, most probably before differentiation of the three major germ layers (endoderm, mesoderm, ectoderm), and therefore after the first cell division and before the late blastocyst stage of development. ${ }^{28}$ Alternatively, an uncorrected half chromatid mutation in one of the parental gametes could have established mosaicism after the first mitotic division after conception. ${ }^{29}$ As a third possibility, the mother could be a chimera consisting of two fertilised eggs, one carrying the mutation $^{30}$; in this case, the grandmother could also be a carrier. In our study, the grandmother was not a carrier as she does not carry the at risk allele.

In the probands' mother, germline mosaicism, either isolated ${ }^{31-34}$ or as part of somatic mosaicism, ${ }^{26}{ }^{35-37}$ has been documented in a growing number of $\mathrm{X}$ linked disorders and germline mosaicism cannot be excluded in the non-carrier mothers of sporadic cases. Therefore, the risk for mosaicism in families with isolated cases might be higher than previously reported. Bakker et $a l^{\beta 2}$ estimated that the incidence of gonadal mosaicism could be as high as $14 \%$ for the at risk haplotype in new cases of DMD. Forty three families with a sporadic case of Hunter disease were studied in our laboratory. In four cases the proband's mother was not found to be a carrier of the mutation and germinal mosaicism could not be excluded. Prenatal diagnosis should consequently be offered to every mother of a sporadic case. 
We thank Drs J J Hopwood, J L Mandel, T J M Hulsebos, and G R Sutherland for providing probes pB2Sc17, U6.2-20E, II-10, and VK21A respectively, and Drs F Prieur and G Bourrouillou for karyotype analysis. This work was supported by "Vaincre les Maladies Lysosomales" (VML) and "Programme Hospitalier de Recherche Clinique" (PHRC).

1 Neufeld EF, Muenzer J. The mucopolysaccharidoses. In: Scriver CR, Beaudet $\mathrm{AL}$, Sly WS, Valle $\mathrm{D}$, eds. The metabolic basis of inherited disease. 7th ed. New York: McGraw-Hill: 1995:2465-94.

2 Wilson PJ, Suthers GK, Callen DF, et al. Frequent deletions at $\mathrm{Xq} 28$ indicate genetic heterogeneity in Hunter synat Xq28 indicate genetic heterogend

3 Wilson PJ, Morris DS, Anson DS, et al. Hunter syndrome

isolation of an iduronate-2-sulfatase cDNA clone and isolation of an iduronate-2-sulfatase cDNA clone and analysis

4 Flomen RH, Green EP, Green PM, Bentley DR, Giannelli F. Determination of the organisation of coding sequences within the iduronate sulphate sulphatase (IDS) gene. Hum Mol Genet 1993;2:5-10.

5 Wilson PJ, Meaney CA, Hopwood JJ, Morris CP. Sequence of the iduronate-2-sulfatase (IDS) gene. Genomics 1993;17 773-5.

6 Timms KM, Lu F, Shen Y, et al. $130 \mathrm{~kb}$ of DNA sequence reveals two new genes and a regional duplication distal to the human iduronate-2-sulfate sulfatase locus. PCR the human iduronate-2-sulfate sulf
Methods and Applications 1995;5:71-8.

7 Bondeson ML, Dahl N, Malmgren H, et al. Inversion of the IDS gene resulting from recombination with IDS-related IDS gene resulting from recombination with IDS-related
sequences is a common cause of the Hunter syndrome. sequences is a common cause

8 Birot AM, Bouton O, Froissart R, Maire I, Bozon D. IDS gene-pseudogene exchange responsible for an intragenic deletion in a Hunter patient. Hum Mutat 1996;8:44-50.

9 Hopwood JJ, Bunge S, Morris CP, et al. Molecular basis of mucopolysaccharidosis type II: mutations in the iduronate2-sulphatase gene. Hum Mutat 1993;2:435-42.

10 Jonsson JJ, Aronovich EL, Braun SE, Whitley CB. Molecular diagnosis of mucopolysaccharidosis type II (Hunter syndrome) by automated sequencing and computerassisted interpretation: toward mutation mapping of the iduronate-2-sulfatase gene. Am $\mathcal{F}$ Hum Genet 1995;56:597607.

11 Goldenfum SL, Young E, Michelakakis H, Tsagarakis S, Winchester $B$. Mutation analysis in 20 patients with Hunter disease. Hum Mutat 1996;7:76-8.

12 Olsen TC, Eiken HG, Knappskog PM, et al. Mutations in the iduronate-2-sulfatase gene in five Norwegians with Hunter syndrome. Hum Genet 1996;97:198-203.

13 Migeon BR, Sprenkle JA, Liebaers I, Scott JF, Neufeld EF. $\mathrm{X}$-linked Hunter syndrome: the heterozygous phenotype in cell culture. Am f Hum Genet 1977;29:448-54.

14 Yutaka T, Fluharty AL, Stevens RL, Kihara H. Iduronate sulfatase analysis of hair roots for identification of Hunter syndrome heterozygotes. Am 7 Hum Genet 1978;30:57582.

15 Gal A, Beck M, Sewell AC, Morris CP, Schwinger E, Hopwood JJ. Gene diagnosis and carrier detection in Hunter wood Jome by the iduronate-2-sulphatase cDNA probe. $f$ syndrome by the iduronate-2-sulp.
Inherited Metab Dis 1992;15:342-6.

16 Hopwood JJ. $\alpha$-L-iduronidase, $\beta$-D-glucuronidase and 2-sulfo-L-iduronate-2-sulfatase: preparation and charac2-sulfo-L-iduronate-2-sulfatase: preparation and characterization of radioactive

17 Wasteson A, Neufeld EF. Iduronate sulfatase from human plasma. Methods Enzymol 1982;43:573-8.

18 Jeanpierre $M$. A rapid method for the purification of DNA from blood. Nucleic Acids Res 1987;15:9611.
19 Hulsebos TJM, Oostra BA, Broersen S, Smits A, van Oost BA, Westerveld A. New distal marker closely linked to the fragile X locus. Hum Genet 1991;87:369-72.

20 Rousseau F, Vincent A, Oberle I, Mandel JL. New informative polymorphism at the DXS 304 locus, a close distal marker for the fragile X locus. Hum Genet 1990;84:263-6.

21 Suthers GK, Callen DF, Hyland VJ, et al. A new DNA marker tightly linked to the fragile X locus (FRAXA). Science 1989;246:1298-300.

22 Weber C, Oudet C, Johnson S, Schlessinger D, Hanauer A. Dinucleotide repeat polymorphism close to IDS gene in $\mathbb{D}$ Xq27.3-q28 (DXS 1113). Hum Mol Genet 1993;2:612.

23 Sukegawa K, Tomatsu S, Tamai K, et al. Intermediate form . of mucopolysaccharidosis type II (Hunter disease): a $\mathrm{C}^{1327}$ to T substitution in the iduronate sulfatase gene. Biochem Biophys Res Commun 1992;183:809-13.

24 Bunge S, Steglich C, Beck M, et al. Mutation analysis of the iduronate-2-sulfatase gene in patients with mucopolysaccharidosis type II (Hunter syndrome). Hum Mol Genet 1992;1:335-9.

25 Froissart R, Blond JL, Maire I, et al. Hunter syndrome: gene deletions and rearrangements. Hum Mutat 1993;2:138-40. है

26 Sommer SS, Knöll A, Greenberg CR, Ketterling RP. Germline mosaicism in a female who seemed to be a carrier by sequence analysis. Hum Mol Genet 1995;4:2181-2.

27 Ben Simon-Schiff E, Bach G, Zlotogora J, Abeliovich D. Combined enzymatic and linkage analysis for heterozygote detection in Hunter syndrome: identification of an detection in Hunter syndrome: identification of an apparent case of

28 Kontusaari S, Tromp G, Kuivaniemi H, Stolle C, Pope FM, Prockop DJ. Substitution of aspartate for glycine 1018 in the type III procollagen (COL3A1) gene causes type IV i Ehlers-Danlos syndrome: the mutated allele is present in $\vec{\omega}$ most blood leukocytes of the asymptomatic and mosaic mother. Am f Hum Genet 1992;51:497-507.

29 Cantu JM, Rivas F, Rivera H, Ruiz C. The prezygotic origin of structural mosaicisms. Ann Genet (Paris) 1985;28:73-4.

30 Witkowski R. Germinal "mosaicism" - germline mutation or chimerism? Hum Genet 1992;88:359-60.

31 Darras BT, Blattner P, Harper JF, Spiro AJ, Alter S, Francke $\mathrm{U}$. Intragenic deletions in 21 Duchenne muscular dystrophy (DMD)/Becker muscular dystrophy (BMD) familie studied with the dystrophin CDNA: location of breakpoint on HindIII and BglII exon-containing fragment maps, meiotic and mitotic origin of the mutations. Am $\mathcal{F}$ Hum Genet 1988;43:620-9.

32 Bakker E, Veenema H, den Dunnen JT, et al. Germinal mosaicism increases the recurrence risk for "new" Duchenne muscular dystrophy mutations. 7 Med Genet 1989;26: 553-9.

33 Gitschier J, Levinson B, Lehesjoki AE, de la Chapelle A. Mosaicism and sporadic haemophilia: implications for carMosaicism and sporadic haemoph

34 Wilton SD, Chandler DC, Kakulas BA, Laing NG. Identification of a point mutation and germinal mosaicism in a Duchenne muscular dystrophy family. Hum Mutat 1994;3 133-40.

35 Bröcker-Vriends AHJT, Briët E, Dreesen JCFM, et al. Somatic origin of inherited haemophilia. Hum Genet 1990 85:288-92.

36 Voit T, Neuen-Jacob E, Mahler V, Jauch A, Cremer $M$ Somatic mosaicism for a deletion of the dystrophin gene in a carrier of Becker muscular dystrophy. Eur 7 Pediatr 1992; 151:112-16.

37 Bunyan DJ, Robinson DO, Collins AL, Cockwell AE, Bullman HMS, Whittaker PA. Germline and somatic mosaicism in a female carrier of Duchenne muscular dystrophy. Hum Genet 1994;93:541-4. 